\title{
The Patterns of Labeling of Plasma Cells and Pyroninophilic Blast Cells with Tritiated Deoxycytidine and Thymidine
}

\author{
By \\ Bunsuke OSOGOE and Hajime MIYAMOTO* \\ Department of Anatomy, Kawasaki Medical School, Matsushima, Kurashiki 701-01, \\ and *Department of Anatomy, Faculty of Medicine, Kyoto University, \\ Sakyo-ku, Kyoto 606, Japan \\ -Received for Publication, May 15, 1978-
}

Key Words: Plasma cells, Pyroninophilic blast cells, Labeling with ${ }^{3} \mathrm{H}$-deoxycytidine.

\begin{abstract}
Summary. By the autoradiographic techniques using ${ }^{3} \mathrm{H}$-deoxycytidine $\left({ }^{8} \mathrm{HdCyd}\right)$ and ${ }^{3} \mathrm{H}$-thymidine ( ${ }^{3} \mathrm{HdThd}$ ), the patterns of labeling of plasma cells and pyroninophilic blast cells (immunoblasts), which are proliferating in response to antigenic stimulation, were studied in comparison with the labeling patterns of germinal-center cells.

The majority of plasma cells and immunoblasts were much more heavily labeled with ${ }^{3} \mathrm{HdTh}$ than were the germinal-center cells. On the contrary, the ability to utilize ${ }^{3} \mathrm{HdCyd}$ of the former two cell types was definitely inferior to that of the latter cell type. However, either plasma cells or immunoblasts were intermingled with a smaller number of cells which were as intensely labeled with ${ }^{3} \mathrm{HdCyd}$ as were the germinal-center cells. Such cells are most likely the progenitors of plasma cells or immunoblasts.
\end{abstract}

Previous studies have demonstrated that lymphocytes in the thymic cortex (thymocytes) and germinal-center cells of the lymph nodes, spleen and Peyer's patches are much more intensely labeled with tritiated deoxycytidine ( $\left.{ }^{3} \mathrm{HdCyd}\right)$ than with tritiated thymidine ( $\left.{ }^{8} \mathrm{HdThd}\right)$ (Osogoe and Ueki 1970, Osogoe et al. 1973, Amano and Osogoe 1975). It has also been shown that large lymphocytes (pyroninophilic blast cells) which occur outside the germinal centers are characterized by intense labeling with ${ }^{3} \mathrm{HdThd}$ in contrast to weak labeling with ${ }^{3} \mathrm{HdCyd}$. The purpose of the present work is to gain further information about the patterns of labeling of cells of the lymphoid series with ${ }^{3} \mathrm{HdCyd}$ and ${ }^{3} \mathrm{HdThd}$, particularly those of plasma cells and pyroninophilic blast cells or immunoblasts of Dameshek (1963) which are proliferating in response to antigenic stimulation.

In the literature there are reported a number of papers dealing with the kinetics of plasma cells or immunoblasts by the autoradiographic techniques using ${ }^{8}$ HdThd (Schooley 1961, Miller 1964, Oort and Turk 1965, Miller and Cole 1967, Tsutsui 1967, Tsutsui et al. 1975). However, labeling experiment of these cells with ${ }^{3} \mathrm{HdCyd}$ has not yet been reported 
except for the work of Tsutsui et al. (1975). In the in-vitro cultures of rat lymphocytes added with phytohemagglutinin (PHA), these authors observed more extensive labeling of blast cells with ${ }^{3} \mathrm{HdCyd}$ than with ${ }^{3} \mathrm{HdThd}$.

\section{Materials and Methods}

In order to produce an extensive proliferation of plasma cells in the mesenteric lymph nodes, sixteen male rats of the Wistar strain weighing about $200 \mathrm{~g}$ were injected intraperitoneally with $1 \mathrm{ml}$ of $20 \%$ sheep red blood cells mixed with 1 $\mathrm{ml}$ of Freund's complete adjuvant in a single dose. After 10 days, the rats were divided into two groups. One group received a single intraperitoneal injection of $\left[\mathrm{G}-{ }^{3} \mathrm{H}\right] \mathrm{dCyd}$ (specific activity $5.5 \mathrm{Ci}$ per mmole) in a dose of $1 \mathrm{~m} \mathrm{Ci}$ per rat. A second group was injected similarly with [methyl $\left.-{ }^{3} \mathrm{H}\right] \mathrm{dThd}$ (specific activity of $6.7 \mathrm{Ci}$ per mmole) in a single dose of $1 \mathrm{~m} \mathrm{Ci}$ per rat. Two rats of each group were sacrificed at 6 hours and at 1, 3, 7 days after the injection of radioactive DNA precursors. Mesenteric lymph nodes, thymus and spleen were fixed in Carnoy fixative, and 4-7 $\mu$ thick paraffin sections were made.

In another series of experiments, four adult rabbits weighing around $2 \mathrm{~kg}$ were injected with $2 \mathrm{ml}$ of $20 \%$ sheep red blood cells into the footpads of both hind legs. After 3 days, the popliteal lymph nodes were greatly enlarged. In two rabbits, the enlarged politeal nodes received a single intranodal injection of either ${ }^{3} \mathrm{HdCyd}$ or ${ }^{3} \mathrm{HdTh}$ in a dose of $100 \mu \mathrm{Ci}$ per node. One hour thereafter, the injected nodes were excised and smear preparations were made. In the other two rabbits, the efferent lymph from the enlarged popliteal nodes was cannulated by the use of a polyethylene tube. The collected lymph $(5-6 \mathrm{ml})$ con- taining numerous cells was centrifuged. The deposited cells were then washed twice with Hank's solution and resuspended in a medium consisting of $80 \%$ Eagle's MEM, 20\% heat-inactivated rabbit serum and 100 units of penicillin and 100 $\mu \mathrm{g}$ streptomycin per $1 \mathrm{ml}$. The suspensions contained $1-5 \times 10^{7}$ cells per $1 \mathrm{ml}$. The cell suspensions were added with either ${ }^{3} \mathrm{HdCyd}$ or ${ }^{3} \mathrm{HdThd}$ in a concentration of $1 \mu \mathrm{Ci}$ per $1 \mathrm{ml}$ and incubated for one hour at $37^{\circ} \mathrm{C}$ in $5 \% \mathrm{CO}_{2}$ in air. Then the suspemsions were centrifuged and smear preparations were made. The smears were fixed with Carnoy fixative.

Autoradiographs were made using Sakura NR-M2 liquid emulsion. The exposure time was 4-12 weeks for sectsons and 7-14 days for smears. Both sections and smears were stained with pyroninemethyl green or Giemsa solution after photographic processing.

\section{Results}

In the mesenteric lymph nodes of the rats that had received a single intraperitoneal injection of sheep red blood cells mixed with complete Freund's adjuvant 10 days previously, there occurred an extensive prolifeation of plasma cells in the mdeullary cords, forming numerous small or large foci of aggregation of these cells around small veins. The pretreatnent of the rats also produced new formation and enlargement of germinal centers and a considerable increase in the number of immunoblasts which are normally present in the paracortical areas outside the germinal centers.

When examined 6 hours after the injection of the labeled DNA precursors, the majority of germinal-center cells were heavily labeled with ${ }^{3} \mathrm{HdCyd}$, but the labeling with ${ }^{3} \mathrm{HdThd}$ was considerably weak. In contrast, many immunoblasts which occurred outside the germinal 
centers showed much more intensive labeling with ${ }^{3} \mathrm{HdThd}$ than that with ${ }^{3} \mathrm{HdCyd}$ (Figs. 1-4, Plate I). Labeling of plasma cells did not take place as yet except for some immature forms, probably plasmablasts.

At 24 hours after injection of the isotopic markers, many plasma cells became labeled but their labeling patterns differed from those of the germinalcenter cells. With ${ }^{3} \mathrm{HdCyd}$, labeling of plasma cells took place to a much lesser extent than that of germinal-center cells (Figs. 5 and 6, Plate II). With ${ }^{8} \mathrm{HdThd}$, on the other hand, the plasma cells revealed much more intensive labeling than did the germinal-center cells (Figs. 7 and 8 , Plate II). It should be emphasized, however, that a minor portion of cells of plasma cell series (about one third or one fourth of these cells) were as heavily labeled with ${ }^{3} \mathrm{HdCyd}$ as were the geminal-center cells (Figs. 5 and 6, Plate II). Such cells are to be classified as plasmablasts, since in these cells the nucleus was larger in size, less condensed and the cytoplasm less pyroninophilic than in the mature plasma cells.

After 72 hours, label of plasma cells was greatly decreased in intensity and nearly completely lost after 7 days. By this time, label of germinal-center cells also disappeard almost completely.

In the popliteal lymph nodes of the rabbits, which had been injected with sheep red blood cells into the footpads three days before, there appeared large pyroninophilic blast cells (immunoblasts) in large numbers. One hour after the intranodal injection of the isotopic markers, these blast cells were much more intensely labeled with ${ }^{3} \mathrm{HdThd}$ than with ${ }^{3} \mathrm{HdCyd}$ (Figs. 9 and 10, Plate III). Similar patterns of labeling were also observed in the case of in vitro labeling of the immunoblasts which had been collected by cannulation of the efferent lylmphatics from the lymph nodes stimulated with antigen (Figs. 11 and 12, Plate III). Among immunoblasts, however, there appeared a smaller number of blast cells which excetionally showed intensive labeling with ${ }^{8} \mathrm{HdCyd}$ as did the germinalcenter cells (Fig. 11. Plate II). Such blast cells, like the germinal-center cells, were weakly labeled with ${ }^{3} \mathrm{HdThd}$ and bore characteristic features of cellular immaturity. They were remarkably smaller in size, the chromatin net work of their nucleus much finer, and the pyroninophilia (or basophilia) of their cytoplasm considerably weaker, as compared with the other blast cells.

\section{Discussion}

The present study has demonstrated that the majority of plasma cells and immunoblasts are much more intensely labeled with ${ }^{3} \mathrm{HdThd}$ than are the germinal-center cells, and that with respect to the ability to utilize ${ }^{3} \mathrm{HdCyd}$ the former two types of cells are definitely inferior to that of the germinalcenter cells. Earlier studies have revealed that the thymocytes and germinalcenter cells are capable of utilizing dCyd for the formation of DNA-thymine, whereas in the majority of immunoblasts the capacity for synthesizing DNAthymine endogenously from dCyd is very limited (Osogoe and Ueki 1970, Osogoe et al. 1973). It is worthy of notice that the plasma cells are similar to immunoblasts as regards the lesser ability of utilizing $\mathrm{dCyd}$ for the DNA-synthesis.

The cell populations of the lymphoid series, like other renewing cell populations, may be divided into three compartments, according to the differences in stage of maturation of the cells, as follows: (1) stem cells or progenitor cells which divide throughout life and thus give rise to both differentiating 
cells and cells similar to themselves; (2) differentiating cells which, in response to antigenic or other kind of stimulation, are differentiating to become effector cells or mature cells; and (3) effector cells such as antibody-producing cells or matura cells which do not divide.

It is well established that both the thymocytes and germinal-center cells rapidly divide, so that the cell populations are completely renewed within severel days (Osogoe and Awaya 1958, Kawamura 1960, Osogoe et al. 1960). Moreover, it has repeatedly been demonstrated that some of the thymocytes migrate to lymph nodes and give rise to T-cells (Miller 1961, Harris and Ford 1964, Nossal 1964, Weisman 1967, Owen and Ruff 1970). Although convincing evidence is still lacking, it is now believed that some of the germinal-center cells also migrate to the medulla to become B-cells (Greaves et al. 1973). As regards the patterns of labeling with ${ }^{3} \mathrm{HdCyd}$ and ${ }^{3} \mathrm{HdThd}$, our earlier and present studies have revealed thot both the thymocytes and the germinal-center cells are intensely labeled with ${ }^{3} \mathrm{HdCyd}$ in contrast to weaker labeling with ${ }^{3} \mathrm{HdThd}$, and there is no essetial difference in the labeling patterns between the two cell types. Accordingly, it seems reasonable to regard the immature forms of not only the thymocytes but also the germinal-center cells as the progenitors of the lymphoid series.

Another important finding of the present study is that, in either the medullary cords or the effernt lymph of the lymph nodes stimulated with antigen, there appeared the cells which were as intensely labeled with ${ }^{3} \mathrm{HdCyd}$ as were the germinar-center 'cells in fairly large numbers. Such cells were found mixed with plasma cells or immunoblasts and showed morphological features characteristic of immature cell types. Similar findings have been reported by Tsutsui et al. (1975). During the process of rat lymphocytes cultured in vitro added with PHA, these authors observed more intensive labeling of newly formed blast cells with ${ }^{3} \mathrm{HdCyd}$ than with ${ }^{3} \mathrm{HdThd}$. However, the labeling intensity with ${ }^{3} \mathrm{HdCyd}$ decreased with increase of the culture days elapsed, while that with ${ }^{3} \mathrm{HdThd}$ increased. These observations indicate that the blast cells have stem cell capacity in the early stages of blastogenesis but such capacity is lost at later stages. The same sequence of events seems to occur during the process of differentiation or maturation of plasma cells.

From the foregoing discussion it is concluded that heavy labeling with ${ }^{3} \mathrm{HdCyd}$ takes place selectively in the immature lymphoid clls which have stem cell capacity. Such cells occur not only within the germinal centers but also outside the centers, mixed with plasma cells or immunoblasts. The cells which are similar in labeling patterns to the germinal-center cells, but which occur outside the germinal centers, are most likely the progenitors of plasma cells or immunoblasts.

\section{References}

1) Amano, M. and Osogoe, B.: Autoradiographic study on DNA synthesis in lymphoid tissues of the rat using tritiatied thymidine and deoxycytidine. Cell Struct. Funct., 1: 81-92, 1975.

2) Dameshek, W.: "Immunoblasts" and "Immunocyes"-An attempt at a functional nomenclature. Blood, $21: 243-245$. 1963.

3) Greaves, M.F., Owen, J.J.T. and Raff, M.C.: $T$ and B Lymphocytes: Origins, properties and roles in immune responses, Excerpta Medica Amsterdam, American Elsevier Publishing Co., Inc. New York, 1973. pp. 33-36.

4) Harris, J.E. and Ford, C.E.: Cellular traffic of the thymuns : experiments with 
chromosome markers. Evidence that the thymus plays an instructional part. Nature (Lond.), 201 : 884-885, 1964.

5) Kawamura, T.: Variations in the mitotic activity in different regions of lymphoid organs. I. Observations on the thymolymphatic organs of young mature albino rats. Okajimas Fol. anat. jap., 35 : 345365, 1960.

6) Linna, T.J.: Cell migration from the thymus to other lymphoid orgons in hamsters of different ages. Blood, 31 : 727-746, 1968.

7) Miller, J.F.A.P.: Effect of neonatal thymectomy on the immunological responsiveness of the mouse. Proc. Roy. Soc. Ser. B. Biol. Sci., 156 : 415-428, 1962.

8) Miller J.J., III : An autoradiographic study of plasma cells and lymphocyte survival in rat popliteal lymph nodes. J. Immunol., 92 : 673-681, 1964.

9) Miller, J.J., III and Cole, L.J.: The radiation resistance of long-lived lymphocytes and plasma cells in mouse and rat lymph nodes. J. Immunol., 98 : 982990, 1967.

10) Murray, R.G. and Woods, P.A.: Studies on the fate of lymphocytes. III. The migration and metamorphosis of in situ labeled thymic lymphocytes. Anat Rec., 150: 113-128, 1964.

11) Nossal, G.J.V.: Studies on the role of seeding of lymphocytes from the intact guinea pig thymus. Ann. N.Y. Acad. Sci., 120 : 171-181, 1964.

12) Oort, J. and Turk, J.L. : A histological and antoradiographic study of lymph nodes during the development of contact sensitivity in the guinea pig. Brit. J. exp. Path., 46 : 147-154, 1965.
13) Osogoe, B. and Awaya, K.: Turnover of cell populations in blood ond bloodforming tissues. Acta haem. jap., 21 (2) Suppl.: 404-418, 1958.

14) Osogoe, B., Awaya, K., Kawamura, T. and Yoshimatsu, M.: Distribution of mitotic figures in different regions of lymph node. Okajimas Fol. anat. jap., 35 : 267-274, 1960.

15) Osogoe, B. and Ueki, A.: A radioautographic study of the utilization of deoxycytidine for the formation of deoxyribonucleic acid-thymine in lymphocytes. J. Cell Biol., 46 : 403-405, 1970.

16) Osogoe, B., Tyler, R.W. and Everett, N.B.: The patterns of labeling of germinal-center cells with tritiated deoxycytidine. J. Cell Biol., $57: 215-220$, 1973.

17) Owen, J.J.T. ond Ruff, M.C.: Studies on the differentiation of thymus-derived lymphocytes. J. exp. Med., 132: 12161232, 1970.

18) Schooley, J.C.: Autoradiographic observations of plasma cell formation. J. Immunol., 86 : 331-337, 1961.

19) Tsutsui, I.: A concept on lymphogonia (immunoblasts) based on the origin and fate of phytohemagglutinin-induced blast cells from human perepheral blood in vitro. II. A model of phytohemagglutinin. induced lymphocytopoiesis in vitro. Acta haem. jap., 30 : 884-900, 1967.

20) Tsutsui, I., Amano, M. and Everett, N.B.: Changes in pyrimidine metabolism of rat lymphocytes cultured with PHA. J. Reticuloendothelial Soc., 18 : 87-96, 1975.

21) Weisman, I.L.: Thymus cell migration. J. exp. Med., $126:$ 291-304, 1967. 


\section{Explanation of Figures}

\section{Plate I}

Autoradiographs of the mesenteric lymph nodes from the rats stimulated with antigen, 6 hours after intraperitoneal injection of ${ }^{3} \mathrm{HdCyd}$ or ${ }^{8} \mathrm{HdThd}$.

Fig. 1. Labeling with ${ }^{3} \mathrm{HdCyd}$. The germinal-center cells are heavily labeled and densely crowded so that the germinal centers are seen as black spots distinctly demarcated from the surrounding tissue. $\times 60$.

Fig. 2. Labeling with ${ }^{3} \mathrm{HdThd}$. The germinal-center cells are weakly labeled and hence the germinal centers (C) are hardly distinguishable from the surrounding tissue. In contrast, many large lymphocytes which are scattered outside the germinal centers are intensely labeled. $\times 60$.

Fig. 3. Higher magnification of the section shown in Figure. 1. The germinal-center cells are heavily labaled with ${ }^{3} \mathrm{HdCyd}$. Notice that a few intensely labeled eclls are scattered outside the germinal-center. $\times 400$.

Fig. 4. Higher magnification of a portion of the section shown in Figue 2. The cells in the germinal centers $(\mathrm{Gc})$ are weakly labeled with ${ }^{3} \mathrm{HdThd}$, whereas numerous large lymphocytes (pyroninophilic blast cells or immunoblasts) which occur outside the germinal centers show intensive labeling. $\times 400$. 

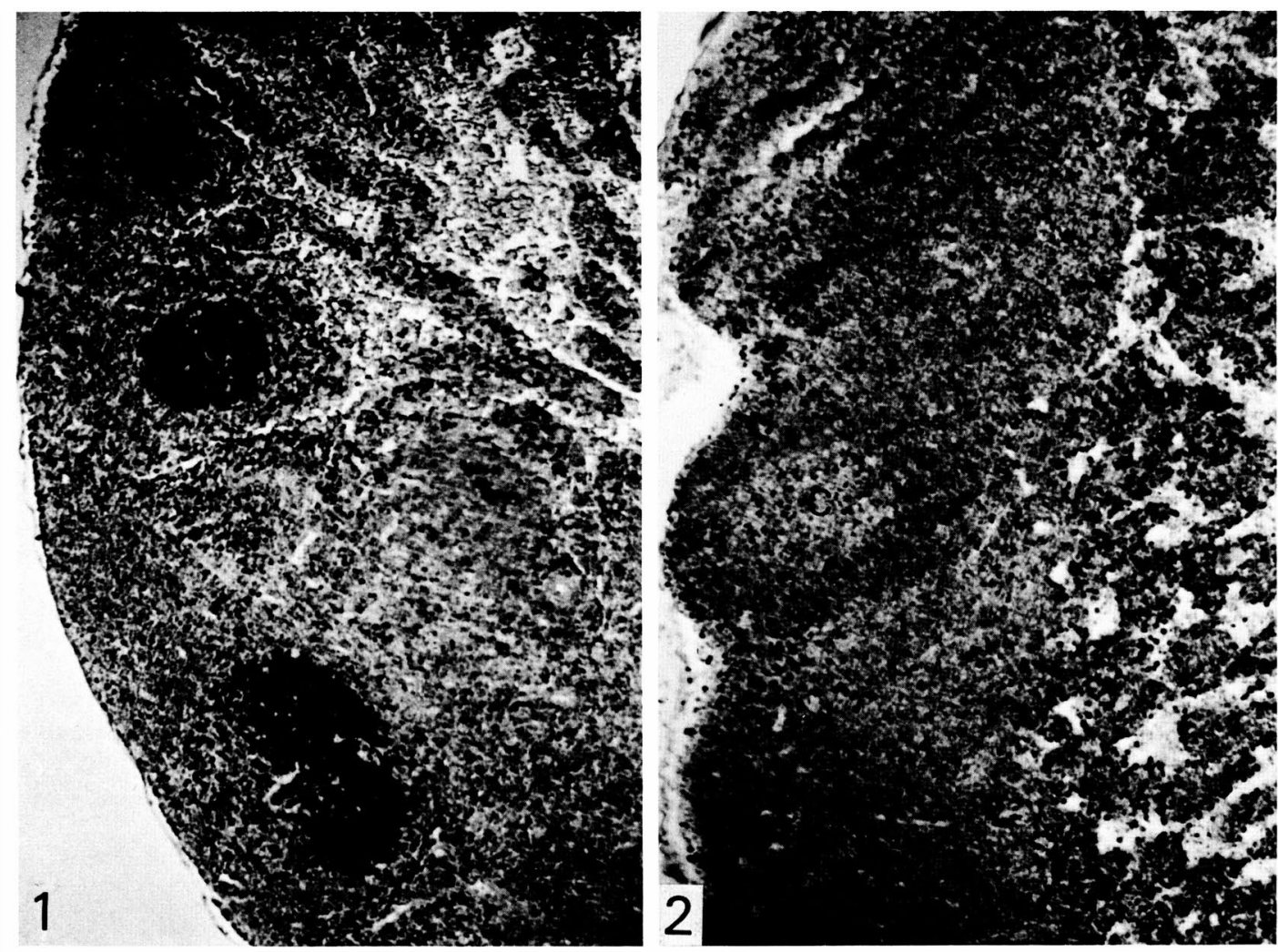

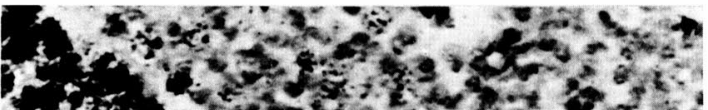

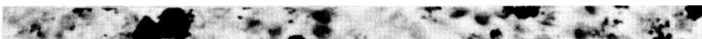

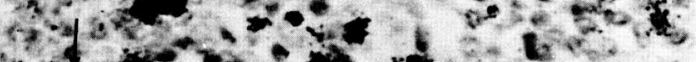

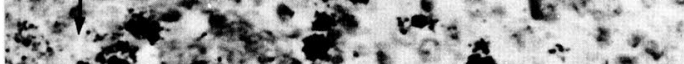

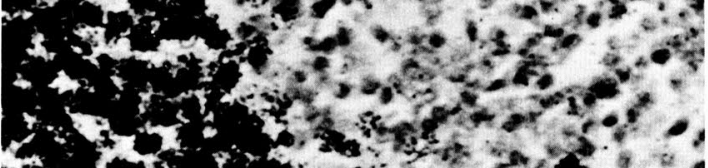

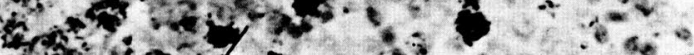

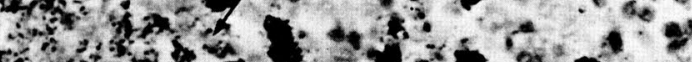

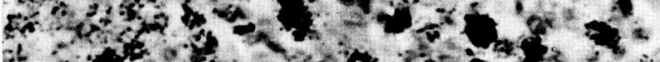

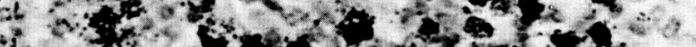
15.

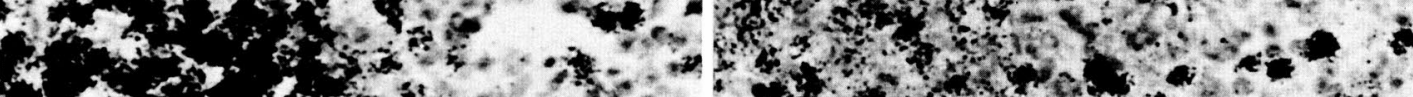

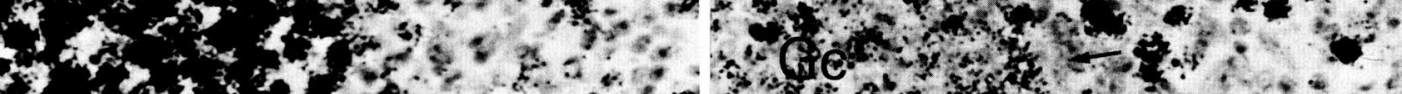

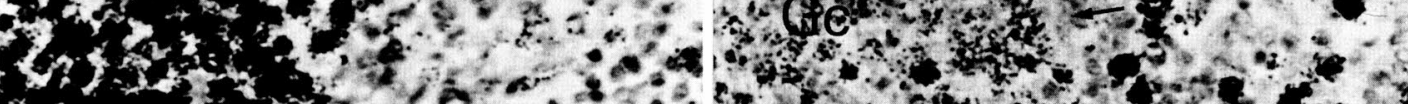
L.

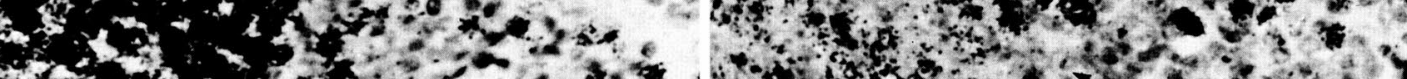

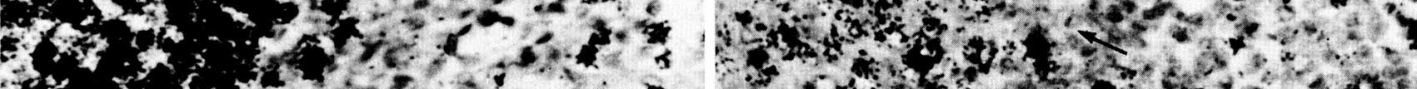

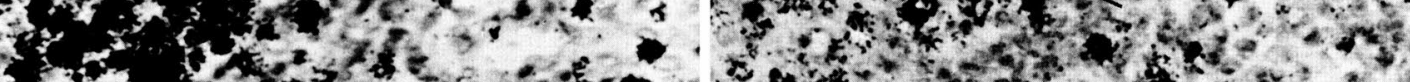

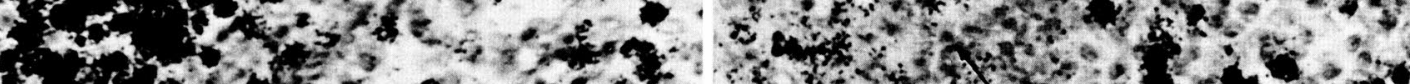

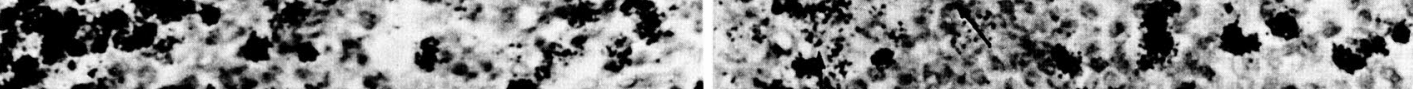

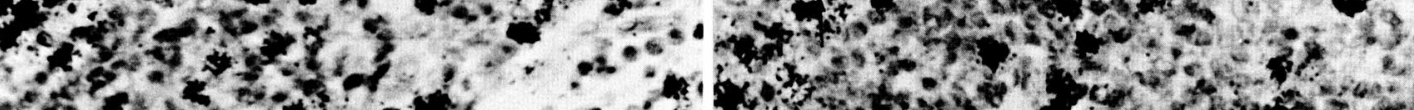

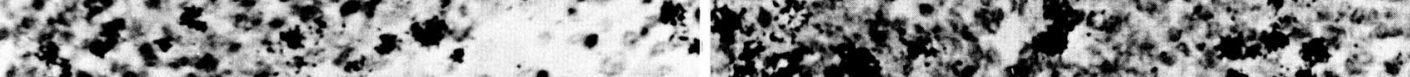

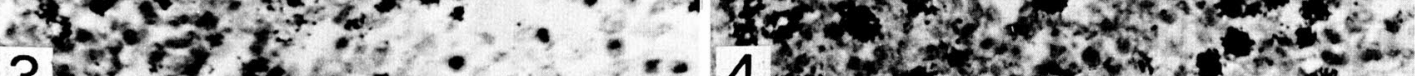

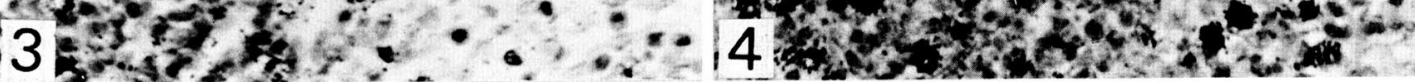

B. Osogoe and H. Miyamoto 


\section{Plate II}

Autoradiographs of the mesenteric lymph nodes from the rats stimulated with antigen in sections, 24 hours after intraperitoneal injection of ${ }^{3} \mathrm{HdCyd}$ or ${ }^{3} \mathrm{HdThd}$.

Fig. 5. Labeling of the germinal-center cells with ${ }^{3} \mathrm{HdCyd}$. The majority of these cells are intensely labeled. $\times 1000$

Fig. 6. Labeling with ${ }^{3} \mathrm{HdCyd}$ of the plasma cells occurring in the medulla of the same section as shown in Figure 5. Notice that labeling of these cells is considerably less intense than that of the germinal-center cells (cf. Fig. 5), except for several cells which are as heavily labeled with ${ }^{3} \mathrm{HdCyd}$ as are the germinal-center cells. $\times 1000$.

Fig. 7. Labeling of the germinal-center cells with ${ }^{3} \mathrm{HdThd}$. These cells are weakly labeled except for a few cells. $\times 1000$.

Fig. 8. Labeling with ${ }^{3} \mathrm{HdTh}$ of the plasma cells occurring in the medulla of the same section as shown in Figure 7. These cells are more intensely labeled than are the germinalcenter cells (cf. Fig. 7). Notice a large blast cell (arrow) which is much more heavily labeled with ${ }^{3} \mathrm{HdThd}$ than are the plasma cells. $\times 1000$. 
Plate II
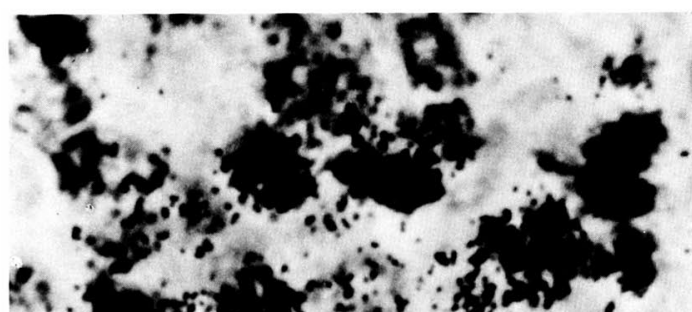

a.

23

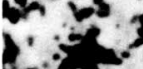

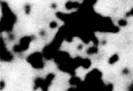

istis

3.

3 action

5.

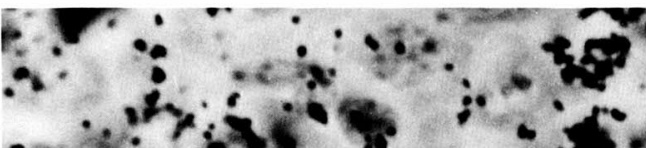

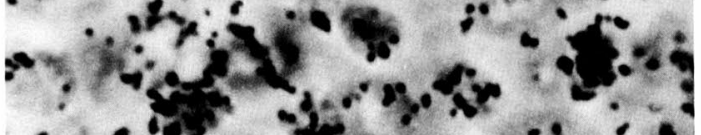

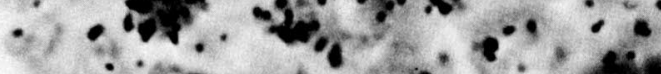
$\therefore-60.00 .0^{\circ} .00$

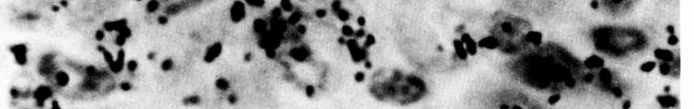

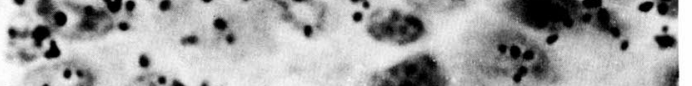
- isil

$\because$ at को $\therefore$ को का

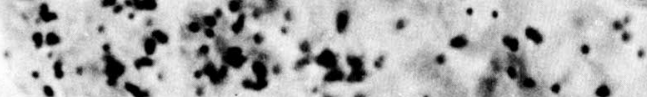

$\because \therefore \%$

$\therefore \quad \therefore \%$.

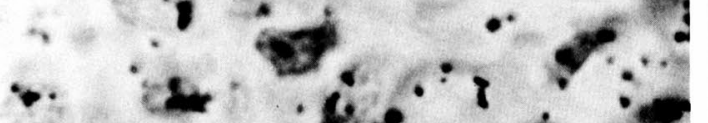

2. 48 - 5 का

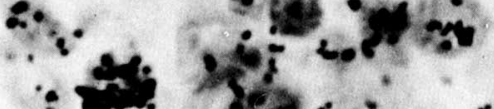
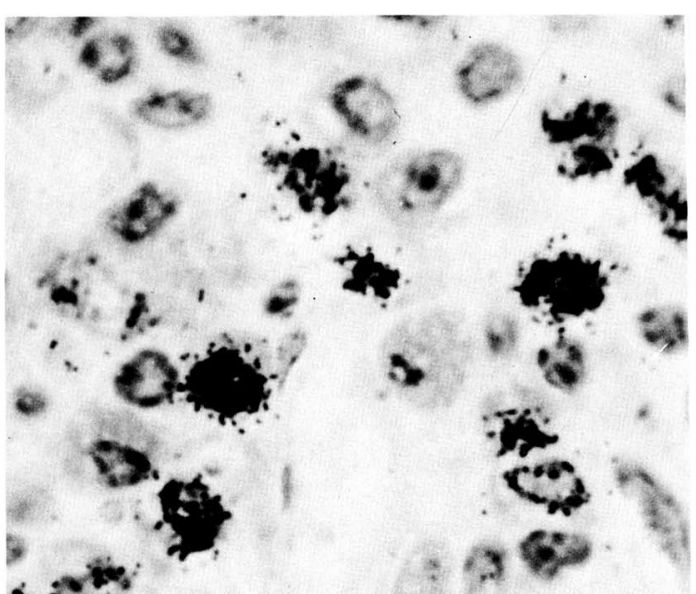

tonth

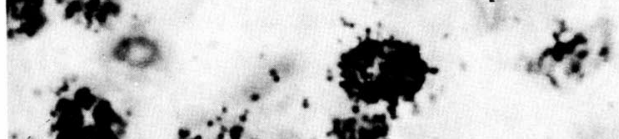




\section{Plate III}

Autoradiographs of the large pyroninophilic blast cells (immunoblasts) occurring in the popliteal lymph nodes from the rabbits stimulated with antigen or in the efferent lymph of these nodes in smear preparations. The cells have been labeled with ${ }^{3} \mathrm{HdCyd}$ or ${ }^{3} \mathrm{HdThd}$ for 1 hour in vivo or in vitro.

Fig. 9. Labeling with ${ }^{3} \mathrm{HdCyd}$ of the pyroninophilic blast cells occurring within the lymph node in vivo, 1 hour after the intranodal injection of the isotopic marker. These cells are weakly labeled except for a few cells. $\times 400$.

Fig. 10. Labeling with ${ }^{3} \mathrm{HdThd}$ of the pyroninophilic blast cells occurring within the lymph node in vivo, 1 hour after the intranodal injection of the isotopic marker. These cells are heavily labeled except for a few cells. $\times 400$.

Fig. 11. Labeling with ${ }^{3} \mathrm{HdCyd}$ of the pyroninophilic blast cells occurring in the efferent lymph after incubating in vitro for 1 hour with the isotopic marker. Notice that, although the majority of these cells are weakly labeled, there are intermingled a few cells which exceptionally show intentensive labeling with ${ }^{3} \mathrm{HdCyd} . \quad \times 400$.

Fig. 12. Labeling with ${ }^{3} \mathrm{HdThd}$ of the pyroninophilic blost cells occurring in the efferent lymph after incubating in vitro for 1 hour with the isotopic marker. These cells are intensely labeled except for a few cells. $\times 400$. 
Plate III

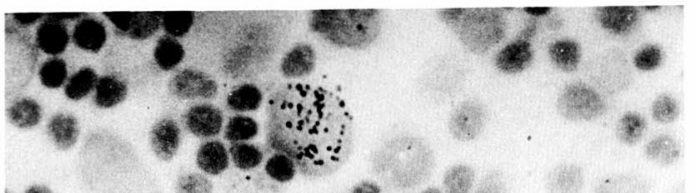

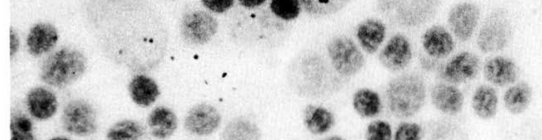

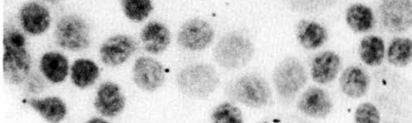

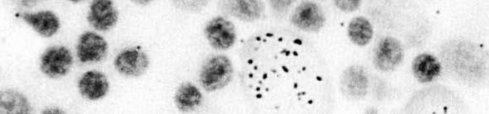

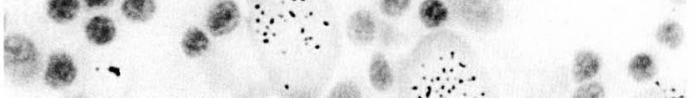

का

- gis

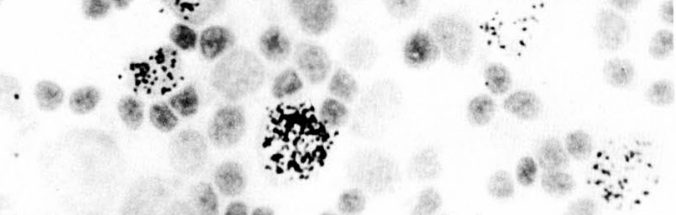

- क

$9: 2 x$

as :

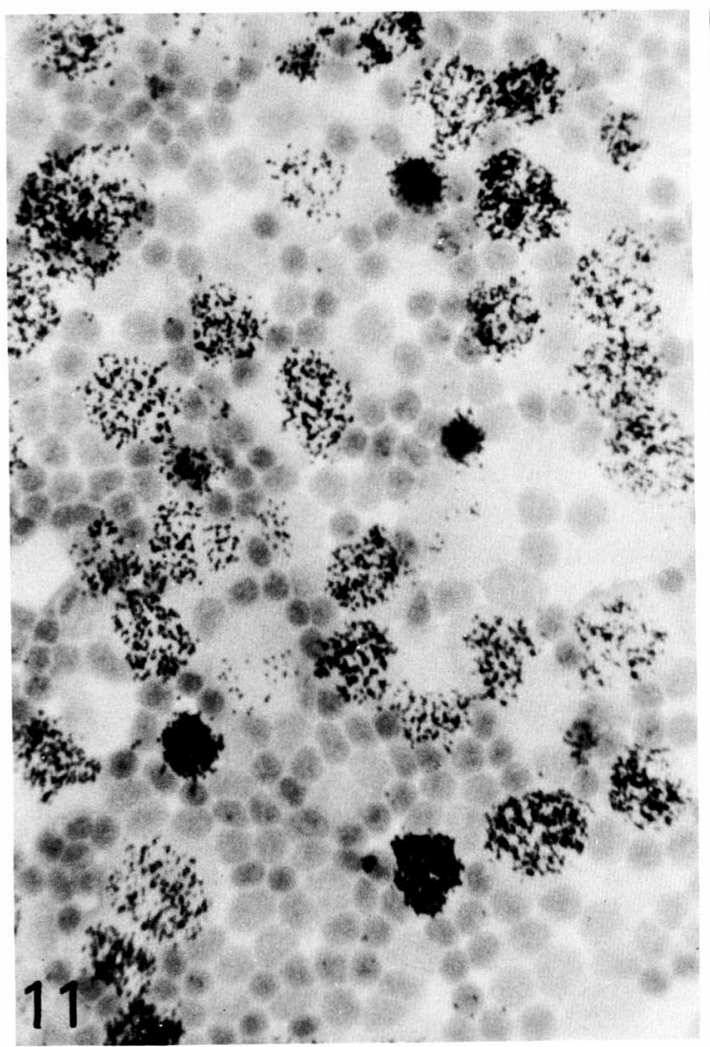

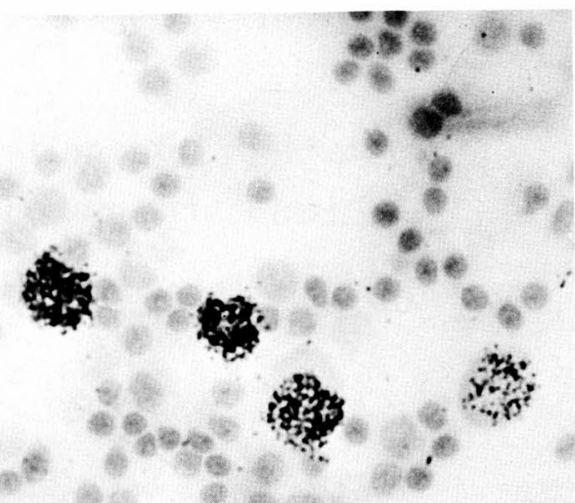
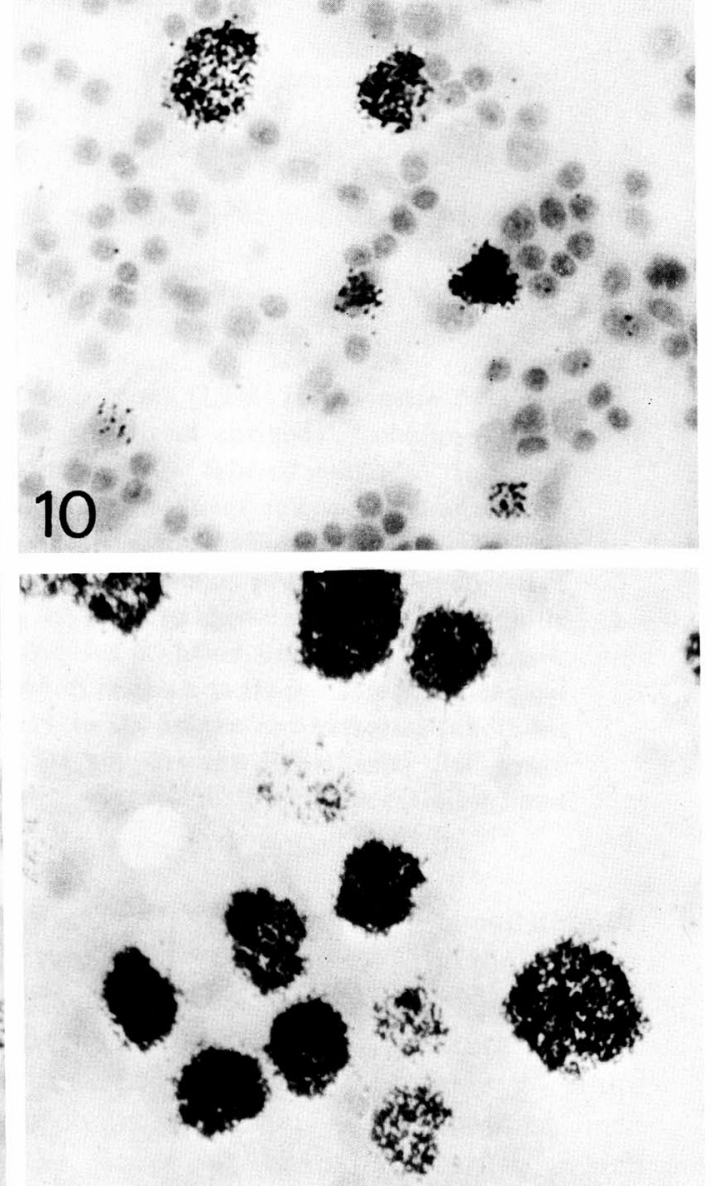

$\pi^{2}$

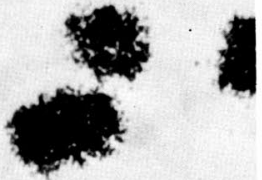

12.

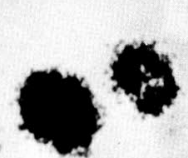

tist.

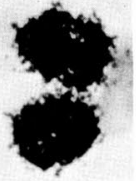

B. Osogoe and H. Miyamoto 